\title{
Adsorption/Desorption Studies of $\mathrm{NO}_{\mathrm{x}}$ on Well-Mixed Oxides Derived from $\mathrm{Co}-\mathrm{Mg} / \mathrm{Al}$ Hydrotalcite-like Compounds
}

\author{
Jun Jie Yu, ${ }^{\dagger}$ Zheng Jiang, ${ }^{\dagger}$ Ling Zhu, ${ }^{\dagger}$ Zheng Ping Hao, ${ }^{*, \dagger}$ and Zhi Ping $\mathbf{X u}{ }^{*, \star}$ \\ Research Center for Eco-Environmental Sciences, Chinese Academy of Sciences, Beijing 100085, PR China, \\ and Australian Research Council (ARC) Centre for Functional Nanomaterials, School of Engineering, \\ The University of Queensland, Brisbane QLD 4072, Australia
}

Received: November 8, 2005; In Final Form: December 22, 2005

\begin{abstract}
$\mathrm{Co}_{x} \mathrm{Mg}_{3-x} / \mathrm{Al}$ hydrotalcite-like compounds (where $x=0.0,0.5,1.0,1.5,2.0,2.5,3.0$ ) were synthesized by the coprecipitation method and characterized by the XRD and TGA techniques. Incorporation of Co for $x=$ 0.0-3.0 gradually decreased the transformation temperature of the hydrotalcites to the corresponding oxides from 444 to $246{ }^{\circ} \mathrm{C}$ and also decreased the surface area from 162.7 to $21.6 \mathrm{~m}^{2} / \mathrm{g}$ upon calcination at $800{ }^{\circ} \mathrm{C}$ for $4 \mathrm{~h}$ in air. The resultant oxide was generally composed of a poor $\mathrm{MgO}$ phase and a spinel phase, with more spinel phase at higher Co incorporation. The derived oxides were tested as the storage/reduction catalysts for $\mathrm{NO}_{x}$ adsorption/desorption. The storage capacity for $\mathrm{NO}_{x}$ was highly dependent on the catalyst composition and storage temperature. In general, more $\mathrm{NO}_{x}$ was stored at lower temperature $\left(100^{\circ} \mathrm{C}\right)$ than that at higher temperature $\left(300^{\circ} \mathrm{C}\right)$, and tertiary catalysts $(x=0.5-2.5)$ stored more $\mathrm{NO}_{x}$ than binary catalyst $(x=0.0$ or 3.0). The catalytic conversion of $\mathrm{NO}$ to $\mathrm{NO}_{2}$ and the catalytic decomposition of $\mathrm{NO}_{x}$ were observed on the tertiary catalysts during $\mathrm{NO}_{x}$ adsorption at $300{ }^{\circ} \mathrm{C}$, which was highly related to the loading of cobalt. The reducibility of catalysts was determined by TPR experiments, and the reduction of cobalt cations started at $150-200{ }^{\circ} \mathrm{C}$ in $\mathrm{H}_{2}$. In situ IR spectra of catalysts adsorbing $\mathrm{NO}_{x}$ revealed that the major $\mathrm{NO}_{x}$ species formed on the catalysts were various kinds of nitrites and nitrates, together with some forms of dimers, such as $\mathrm{N}_{2} \mathrm{O}_{2}{ }^{2-}$ and $\mathrm{N}_{2} \mathrm{O}_{4}$ ( or $\mathrm{NO}^{+} \mathrm{NO}_{3}{ }^{-}$). The storage/reduction mechanism and the function of Co in the mixed oxides are proposed and discussed on the basis of these observations.
\end{abstract}

\section{Introduction}

Various nitrogen oxides $\left(\mathrm{NO}_{x}\right)$, generally produced in the combustion of fossil fuels, are the major pollutants in air that cause some environmental problems, such as photochemical smog and acid rain, as well as some human diseases, such as asthma. ${ }^{1}$ Thus, there is a growing need to reduce emissions of $\mathrm{NO}_{x}$ from automobile combustion, mainly via catalytic decomposition to environmentally friendly $\mathrm{N}_{2}$ and $\mathrm{O}_{2}$. In fact, Pt-Rhbased three-way catalysts (TWCs) can effectively convert $\mathrm{NO}_{x}$ to $\mathrm{N}_{2}$ under conditions of a stoichiometric air-to-fuel ratio. ${ }^{1,2}$ However, the general requirement of more fuel-efficient gasoline engines due to limited fossil fuel resources on the earth drives car manufacturers to develop lean-burn engines that combust fuel more efficiently under excess oxygen. ${ }^{3}$ The presence of excess oxygen in the exhaust severely reduces the activity of three-way catalysts for $\mathrm{NO}_{x}$ decomposition. ${ }^{4}$ Therefore, catalysts that can effectively reduce the $\mathrm{NO}_{x}$ amount in the presence of excess oxygen have now been widely sought, among which $\mathrm{NO}_{x}$ storage/reduction (NSR) catalytic treatment seems a more promising approach to $\mathrm{NO}_{x}$ removal in excess oxygen., 5

$\mathrm{NO}_{x}$ storage/reduction technology is used in engines that alternately operate under lean-burn and rich-burn conditions. ${ }^{7,8}$ Under lean-burn conditions, NO is oxidized and is stored on

* Corresponding authors. Tel.: +86-10-62849194 (Z.P.H.), 61-733469973 (Z.P.X.). Fax: +86-10-62923564 (Z.P.H.), 61-7-33656074 (Z.P.X.). E-mail: zpinghao@mail.rcees.ac.cn (Z.P.H.), zhipingx@ cheque.uq.edu.au (Z.P.X.).

$\dagger$ Chinese Academy of Sciences.

$\doteqdot$ The University of Queensland. the catalyst. When the engine is switched to conditions with a stoichiometric air-to-fuel ratio, i.e., rich-burn conditions, $\mathrm{NO}_{x}$ species are released and subsequently reduced by hydrocarbons and carbon monoxide. ${ }^{9,10} \mathrm{~A}$ model $\mathrm{NO}_{x}$ storage/reduction catalyst comprises three major components: a high-surface-area support material (e.g., $\gamma-\mathrm{Al}_{2} \mathrm{O}_{3}$ ), a $\mathrm{NO}_{x}$ storage component containing alkali or alkaline earth metals (e.g., $\mathrm{Ca}, \mathrm{Sr}, \mathrm{Ba}, \mathrm{K}$, or $\mathrm{Na}$ ), and a noble metal (e.g., Pt, Rh, or Pd) as the catalytic redox component. ${ }^{9-12}$ These storage/reduction catalysts are efficient at removing $\mathrm{NO}_{x}$ under lean-rich cycles in the absence of $\mathrm{SO}_{2}$. Nevertheless, a problem is that $\mathrm{SO}_{2}$ generated in trace amounts in the exhaust dramatically deactivates the storage/ reduction catalysts, ${ }^{13}$ which, together with the high expense of noble metals, demands the development of inexpensive and $\mathrm{SO}_{2}-$ tolerant storage/reduction catalysts with similar or better storage/ reduction performances.

In sharp contrast to the abundant research on the improvement of the model storage/reduction catalyst $\mathrm{Pt}-\mathrm{Ba} / \mathrm{Al}_{2} \mathrm{O}_{3},{ }^{9-19}$ such as introducing other components, including $\mathrm{Fe}, \mathrm{Ce}, \mathrm{Cu}$, and $\mathrm{Ni}$, the search for other alternative catalysts seems to draw less attention. ${ }^{10,12,17,18,20-26}$ Perovskites ${ }^{10,20-23}$ and zeolites ${ }^{24}$ are the primary candidates that show potential as alternative NSR catalysts. Recently, a type of well-mixed and well-dispersed oxides derived from hydrotalcite-like compounds has received considerable attention in the search for alternative NSR catalysts. ${ }^{12,17,18,25,26}$

Hydrotalcite-like compounds (HTlcs), also known as anionic clays or layered double hydroxides (LDHs), are multifunctional materials that are widely used as adsorbents, ion exchangers, base catalysts, and precursors of well-mixed oxides for various 
catalytic applications. ${ }^{27,28}$ HTlcs are a large family of mixed hydroxides and can be chemically expressed by the general formula $\left[\mathrm{M}^{\mathrm{II}}{ }_{1-x} \mathrm{M}^{\mathrm{III}}{ }_{x}(\mathrm{OH})_{2}\right]^{x+}\left(\mathrm{A}^{n-}\right)_{x / n} \cdot m \mathrm{H}_{2} \mathrm{O}$, where $\mathrm{M}^{\mathrm{II}}$ represents any divalent metal cation, $\mathrm{M}^{\mathrm{III}}$ any trivalent metal cation, and $\mathrm{A}^{n-}$ an anion (inorganic or organic). ${ }^{27,28}$ HTlcs can contain metal cations of more than two types, which leaves vast flexibility for the better selection of various cations in these materials for NSR catalyst development. For example, in a mixed oxide derived from an $\mathrm{M}-\mathrm{MgAl} \mathrm{HT}$ compound, $\mathrm{Al}_{2} \mathrm{O}_{3}$ acts as the support; $\mathrm{MgO}$ acts as a $\mathrm{NO}_{x}$ storage component; and $\mathrm{M}\left(\mathrm{M}^{\mathrm{II}}\right.$ and/or $\left.\mathrm{M}^{\mathrm{III}}\right)$ can act as the active component for promoting storage of $\mathrm{NO}_{x}$, conversion of $\mathrm{NO}_{x}$ to $\mathrm{N}_{2}$ and $\mathrm{O}_{2}$, and reduction of $\mathrm{NO}_{x}$ with carbon monoxide and hydrocarbons. In fact, $\mathrm{Cu}$-containing calcined $\mathrm{MgAl}$ HTlcs have been found to be active and selective catalysts of $\mathrm{NO}_{x}$ removal. ${ }^{17,18,29}$ Our recent studies ${ }^{30,31}$ show that these HTlc-derived catalysts perform well for $\mathrm{NO}_{x}$ storage/reduction, especially at low temperatures. Taking into account the fact that cobalt species are active components for $\mathrm{NO}_{x}$ removal and decomposition, ${ }^{32,33}$ we prepared a series of $\mathrm{Co}-\mathrm{Mg} / \mathrm{Al}$ mixed oxide catalysts from the corresponding HTlc precursors upon calcination. These mixed oxide catalysts were tested as storage/reduction catalysts of mixed $\mathrm{NO}$ and $\mathrm{NO}_{2}$ gases at 100 and $300{ }^{\circ} \mathrm{C}$. The storage amount of $\mathrm{NO}_{x}$ was very much related to the catalyst composition, and there should be an optimum NSR catalyst with a careful tradeoff of the $\mathrm{Co} / \mathrm{Mg}$ ratio in the precursor. The storage/ reduction mechanism of $\mathrm{NO}_{x}$ on these catalysts and the effect of cobalt in these processes were further proposed on the basis of the in situ IR spectra and adsorption/desorption experimental data.

\section{Experimental Section}

Materials Preparation. Various $\mathrm{Co}_{x} \mathrm{Mg}_{3-x} / \mathrm{Al}$ hydrotalcitelike compounds with $\left(\mathrm{Co}^{2+}+\mathrm{Mg}^{2+}\right) / \mathrm{Al}^{3+}$ molar ratio fixed at 3.0 were prepared with a constant-pH coprecipitation method where $x$ was set at $0.0,0.5,1.0,1.5,2.0,2.5$, and 3.0 (denoted as $x$ CoMA-HT). Briefly, a mixed salt solution $(100 \mathrm{~mL})$ and a mixed basic solution $(100 \mathrm{~mL})$ were simultaneously added dropwise into $100 \mathrm{~mL}$ of doubly distilled water within $1 \mathrm{~h}$ at constant $\mathrm{pH}(10 \pm 0.5)$ under vigorous mechanical stirring. The salt solution with a total metal concentration of $1.0 \mathrm{M}$ contains suitable amounts of $\mathrm{Mg}\left(\mathrm{NO}_{3}\right)_{2} \cdot 6 \mathrm{H}_{2} \mathrm{O}$ (>99\%, Yili Company), $\mathrm{Co}\left(\mathrm{NO}_{3}\right)_{2} \cdot 6 \mathrm{H}_{2} \mathrm{O}\left(>99 \%\right.$, Jinke Company), and $\mathrm{Al}\left(\mathrm{NO}_{3}\right)_{3} \cdot 9 \mathrm{H}_{2} \mathrm{O}$ ( $>99 \%$, Yili Company), and the basic solution contains $\mathrm{NaOH}$ ( $>96 \%$, Beihua Company) and $\mathrm{Na}_{2} \mathrm{CO}_{3}(>99.8 \%$, Beihua Company) with $\left[\mathrm{OH}^{-}\right] /\left[\mathrm{CO}_{3}{ }^{2-}\right]=16$ and $\left[\mathrm{OH}^{-}\right] /\left[\mathrm{Al}^{3+}\right]=8$. Precipitates were aged in suspension at $60^{\circ} \mathrm{C}$ for $4 \mathrm{~h}$ under stirring in static air and then filtered and thoroughly washed with doubly distilled water. The cake was dried at $70{ }^{\circ} \mathrm{C}$ for 12 $\mathrm{h}$ and again at $120{ }^{\circ} \mathrm{C}$ overnight. As-prepared HTlcs were calcined at $800{ }^{\circ} \mathrm{C}$ for $4 \mathrm{~h}$ to derive corresponding $\mathrm{Co}-\mathrm{Mg} / \mathrm{Al}$ mixed oxide catalysts, denoted as $x \mathrm{CoMAO}(x=0.0,0.5,1.0$, $1.5,2.0,2.5,3.0)$. The oxide catalysts were then crushed, sized in 20-40 mesh for storage/reduction experiments, and kept in a desiccator to avoid reconstruction of the hydrotalcite-like structure.

Materials Characterization. The X-ray diffraction (XRD) patterns of $\mathrm{Co}-\mathrm{Mg} / \mathrm{Al} \mathrm{HT}$ materials ( $x$ CoMA-HTs) and the derived mixed oxides ( $x$ CoMAO) were measured on a Rigaku powder diffractometer (D/MAX-RB) using $\mathrm{Cu} \mathrm{K \alpha}$ radiation $(\lambda=$ $0.15418 \mathrm{~nm}$ ) in the $2 \theta$ range of $10-70^{\circ}$ at a scanning rate of $4^{\circ}$ per min. The tube voltage and current were set at $40 \mathrm{kV}$ and $30 \mathrm{~mA}$, respectively.

Thermal decomposition of $\mathrm{Co}-\mathrm{Mg} / \mathrm{Al}$ HTs ( $x$ CoMA-HTs) was investigated with thermogravimetry (TG, Seteram, Labsys).
In a typical measurement, $20-30 \mathrm{mg}$ of HT sample was heated in an $\mathrm{Al}_{2} \mathrm{O}_{3}$ crucible at a constant heating rate of $10{ }^{\circ} \mathrm{C} / \mathrm{min}$ from 25 to $1000{ }^{\circ} \mathrm{C}$, with air purging at a flow rate of $30 \mathrm{~mL} /$ $\min$.

The textural properties of calcined HTs ( $x$ CoMAO) were analyzed by $\mathrm{N}_{2}$ adsorption/desorption at liquid nitrogen temperature (77 K), using a Quantachrome NOVA-1200 gas absorption analyzer. The specific surface area was calculated with the BET equation, and the pore volume and pore size distribution were obtained with the $\mathrm{BJH}$ method from the adsorption isotherm.

Temperature-programmed reduction (TPR) was performed for all $x$ CoMAO catalysts on a conventional TPR apparatus equipped with a thermal conductivity detector (TCD). In general, the sample $(50 \mathrm{mg})$ was inserted in a quartz tube and sandwiched between two quartz wool plugs. Prior to each TPR run, the oxide catalyst was heated to $500{ }^{\circ} \mathrm{C}$ with $\mathrm{O}_{2}$ flushing $(40 \mathrm{~mL} / \mathrm{min}$ ) for $30 \mathrm{~min}$ and then cooled to room temperature under the oxygen stream. After the flowing gas had been switched, $\mathrm{N}_{2}$ was introduced into the reactor at $50 \mathrm{~mL} / \mathrm{min}$ for $1 \mathrm{~h}$ at room temperature to purge away any residual oxygen. This pretreated oxide catalyst was then heated to $900{ }^{\circ} \mathrm{C}$ at a ramp of $10{ }^{\circ} \mathrm{C} /$ min and reduced in a reducing environment $\left(5 \% \mathrm{H}_{2}\right.$ in $\mathrm{N}_{2}$ at a flow rate of $50 \mathrm{~mL} / \mathrm{min})$. During the heating, hydrogen consumption was monitored by the TCD.

Thermal NO Adsorption/Desorption. Thermal $\mathrm{NO}_{x}$ adsorption experiments were carried out in a quartz flow reactor (i.d. $=8 \mathrm{~mm}$ and $L=600 \mathrm{~mm}$ ) using $1.0 \mathrm{~g}$ of $\mathrm{Co}-\mathrm{Mg} / \mathrm{Al}$ oxide catalyst (20-40 mesh powder). Oxide catalyst was pretreated in a gas flow of $\mathrm{O}_{2} / \mathrm{N}_{2}\left(8 \% \mathrm{O}_{2}\right.$ by volume $)$ at $500{ }^{\circ} \mathrm{C}$ at a constant space velocity of $\sim 30000 \mathrm{~h}^{-1}$ for $1 \mathrm{~h}$ and then cooled to the experimental temperature $\left(100\right.$ or $\left.300{ }^{\circ} \mathrm{C}\right)$. When the temperature had stabilized at 100 or $300^{\circ} \mathrm{C}, 1400 \mathrm{ppm} \mathrm{NO}$ (1300 ppm $\mathrm{NO}$ and $100 \mathrm{ppm} \mathrm{NO}_{2}$ ) and $8 \% \mathrm{O}_{2}$ in $\mathrm{N}_{2}$ were introduced at a rate of $500 \mathrm{~mL} / \mathrm{min}$ for $30 \mathrm{~min}$ for thermal $\mathrm{NO}_{x}$ adsorption. Concentrations of $\mathrm{NO}, \mathrm{NO}_{2}$, and $\mathrm{NO}_{x}$ from the reactor outlet were monitored by a Chemiluminescence NO$\mathrm{NO}_{2}-\mathrm{NO}_{x}$ analyzer (model $42 \mathrm{C}$ High Level, Thermo Electron Corporation).

After the thermal $\mathrm{NO}_{x}$ adsorption, the flow gas was switched to pure $\mathrm{N}_{2}$ (rate $=500 \mathrm{~mL} / \mathrm{min}$, space velocity $\approx 30000 \mathrm{~h}^{-1}$ ) to flush the oxide catalyst for $20 \mathrm{~min}$ and remove the weakly adsorbed species at the adsorption temperature. The oxide catalyst was then cooled to $100{ }^{\circ} \mathrm{C}$ if the adsorption temperature was $300{ }^{\circ} \mathrm{C}$. The temperature programmed desorption (TPD) was then conducted by heating the sample from 100 to $650{ }^{\circ} \mathrm{C}$ at a ramp of $10{ }^{\circ} \mathrm{C}$ per min with $\mathrm{N}_{2}$ flowing at a rate of 500 $\mathrm{mL} / \mathrm{min}$. Concentrations of $\mathrm{NO}, \mathrm{NO}_{2}$, and $\mathrm{NO}_{x}$ from the reactor outlet were monitored by a chemiluminescence $\mathrm{NO}-\mathrm{NO}_{2}-\mathrm{NO}_{x}$ analyzer, and the adsorbed $\mathrm{NO}_{x}$ amount was thus calculated.

In Situ Infrared Monitoring. In situ FT-IR spectra were recorded on a Bruker Tensor 27 spectrometer in the range of $600-4000 \mathrm{~cm}^{-1}$ after 128 scans at a resolution of $4 \mathrm{~cm}^{-1}$. Selfsupporting pellets ( $\sim 50 \mathrm{mg}, 20-40 \mathrm{mesh}$ ) were prepared from the oxide catalysts and used directly in the IR flow cell. The IR cell, made of stainless steel, contained a $\mathrm{KBr}$ window and was connected to a vacuum apparatus with a residual pressure below $10^{-4} \mathrm{~Pa}$. A K-type thermocouple was set in direct contact with the IR flow cell to control the temperature. Prior to the recording of an IR spectrum, the catalyst sample was pumped off for $1 \mathrm{~h}$ at $350{ }^{\circ} \mathrm{C}$ to eliminate impure species on the sample surface. After the sample had cooled to 100 or $300{ }^{\circ} \mathrm{C}$ under vacuum, a spectrum of the treated sample was taken as the 

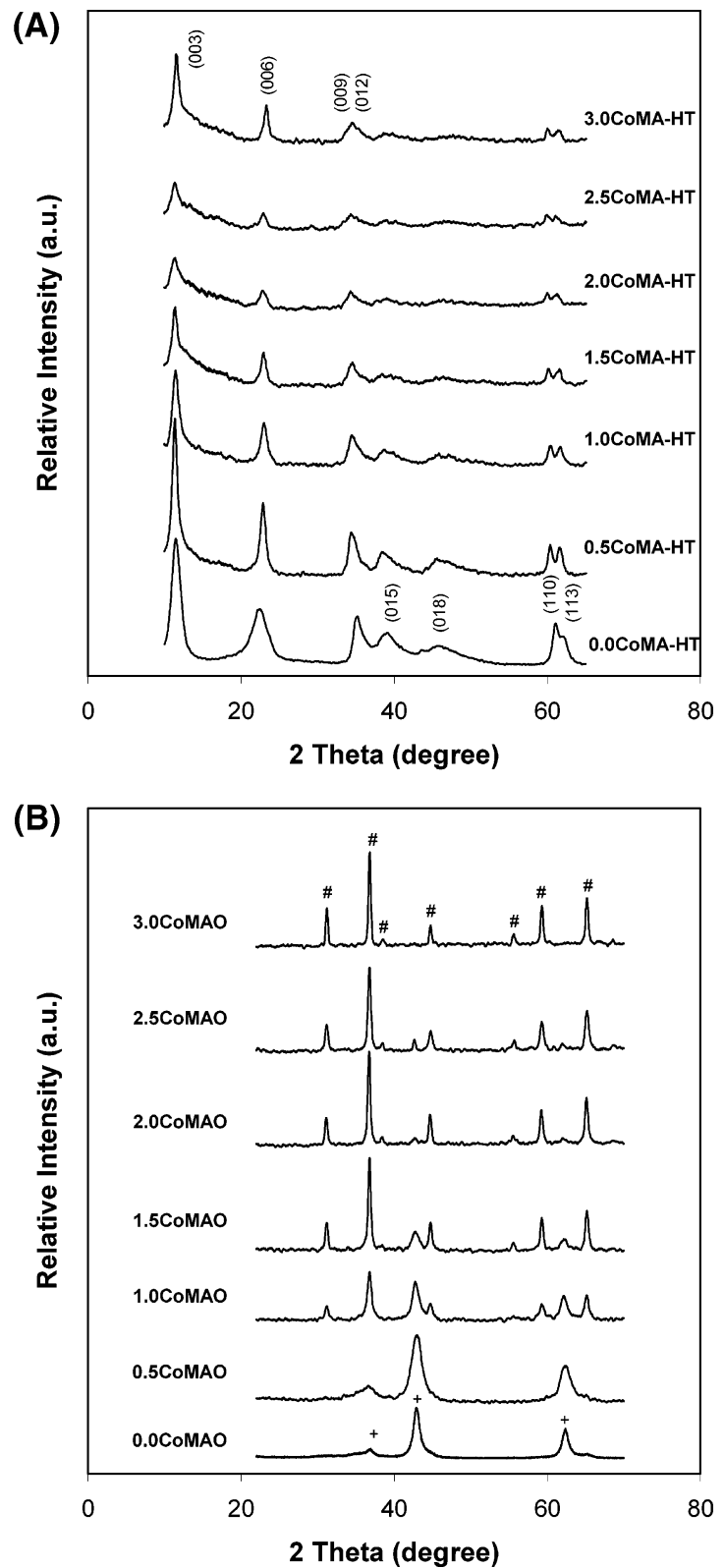

Figure 1. XRD patterns of (A) samples $x$ CoMA-HT and (B) catalysts $x \mathrm{CoMAO}$, where the $\mathrm{MgO}$ phase is marked as "+" and spinel as "\#".

background at that temperature. Then, a mixture gas stream (total flow $25 \mathrm{~mL} / \mathrm{min}$ ) containing $1300 \mathrm{ppm} \mathrm{NO}, 100 \mathrm{ppm} \mathrm{NO}$, and $8 \% \mathrm{O}_{2}$ in $\mathrm{N}_{2}$ was introduced for $\mathrm{NO}_{x}$ adsorption at 100 or 300 ${ }^{\circ} \mathrm{C}$. Meanwhile, the IR spectra were sequentially recorded at the time points of $1,2,5,10,20,30$, and $60 \mathrm{~min}$.

\section{Results and Discussion}

Transformation of Hydrotalcites to Mixed Oxides. Asprepared Co-containing $\mathrm{Mg}-\mathrm{Al}$ hydrotalcites ( $x$ CoMA-HTs) are identified by the X-ray diffraction (XRD) patterns, as shown in Figure $1 \mathrm{~A}$. The peaks at $2 \theta \approx 11^{\circ}, 22^{\circ}$, and $35^{\circ}$ corresponding to the (003), (006), and (009) crystal planes, respectively, indicate relatively well-formed crystalline layered structures with rhombohedral symmetry (3R). ${ }^{27,28}$ On the other hand, the broad diffraction peaks at $\sim 35^{\circ}, 38^{\circ}$, and $46^{\circ}$ attributable to the (012), (015), and (018) crystal planes are characteristic of polytype $3 \mathrm{R}_{1}$ hydrotalcites (JCPDS 22-700). ${ }^{28,34,35}$ The well-defined (110) and (113) diffraction peaks reveal a quite good dispersion of metal ions in the hydroxide layers. The cell parameters $a$ and $c$

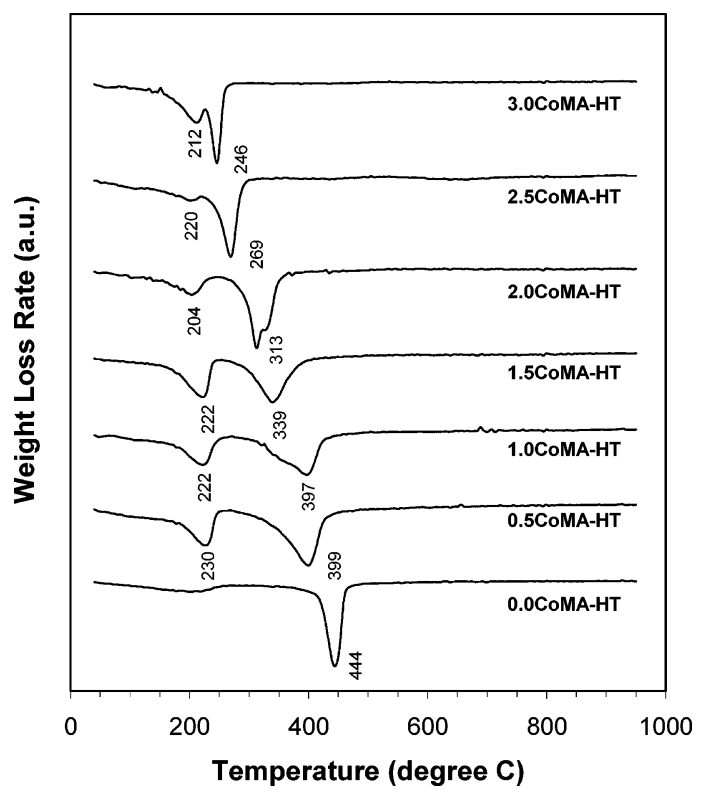

Figure 2. DTG profiles of catalysts $x \mathrm{CoMAO}$ in air.

for all HT samples are 0.306-0.309 and 2.29-2.37 nm, respectively, in good agreement with the reported values. ${ }^{27}$ The incorporation of Co into hydroxide layers seems to affect the crystallinity of the HT crystallites. In particular, the characteristic diffraction peaks of samples 2.0CoMA-HT and 2.5CoMA-HT are much weaker and broader, probably because of the slight incompatibility of $\mathrm{Mg}$ and $\mathrm{Co}$ in the ionic size $(0.072 \mathrm{~nm}$ for $\mathrm{Mg}^{2+}$ vs $0.065 \mathrm{~nm}$ for $\left.\mathrm{Co}^{2+}\right) .{ }^{28}$

The XRD patterns of the derived mixed oxides (Figure 1B) show the complete transformation from the hydrotalcite to the oxide phase. It is obvious that the gradual replacement of $\mathrm{Mg}$ with $\mathrm{Co}$ in the hydrotalcite structure leads to the gradual changes in the phase composition. For sample 0.0CoMAO, i.e., $\mathrm{Mg}_{3} \mathrm{Al}$ oxide, three peaks at $37^{\circ}, 43^{\circ}$, and $62^{\circ}$ are ascribed to the $\mathrm{MgO}$ phase (JCPDS 43-1022, JCPDS 89-7746). The possible spinel phase $\left(\mathrm{MgAl}_{2} \mathrm{O}_{4}, \mathrm{JCPDS} 86-2258\right)$, which is normally observable at $1000{ }^{\circ} \mathrm{C},{ }^{36}$ was not detected. In contrast, for sample 3.0CoMAO, i.e., $\mathrm{Co}_{3} \mathrm{Al}$ oxide, diffraction peaks with $2 \theta$ at $\sim 31^{\circ}, 36^{\circ}, 39^{\circ}, 45^{\circ}, 55^{\circ}, 59^{\circ}$, and $65^{\circ}$ were observed that are only attributed to a spinel phase $\left(\mathrm{Co}_{2} \mathrm{AlO}_{4}\right.$, JCPDS 38-0814; $\mathrm{CoAl}_{2} \mathrm{O}_{4}$, JCPDS 82-2246; $\mathrm{Co}_{3} \mathrm{O}_{4}$, JCPDS 74-2120) ${ }^{37}$ and could be chemically expressed as $\mathrm{Co}_{4 / 3}^{\mathrm{II}} \mathrm{Co}_{5 / 3} \mathrm{AlO}_{16 / 3}$. This formula is supported by the TPR results (refer to section 3.2), suggesting that over half of $\mathrm{Co}^{\mathrm{II}}$ ions are oxidized to $\mathrm{Co}^{\mathrm{III}}$ during calcination in static air. For all tertiary oxides, both $\mathrm{MgO}$ and spinel are detected by XRD (Figure 1B). When more Co is incorporated to replace $\mathrm{Mg}$ in the hydroxide layers, the derived oxide contains more spinel and less $\mathrm{MgO}$. For example, 0.5CoMAO is mainly composed of a $\mathrm{MgO}$ phase with an unnoticeable spinel phase, whereas samples $2.0 \mathrm{CoMAO}$ and $2.5 \mathrm{CoMAO}$ contain very minor amounts of $\mathrm{MgO}$ phase. This observation suggests that introduction of Co into the hydrotalcite promotes the formation of the spinel phase in the oxide catalyst, which is believed to affect the activity for $\mathrm{NO}_{x}$ storage, conversion, and decomposition, as discussed shortly. In addition, the crystallite size of the spinel phase $(20-25 \mathrm{~nm})$ is roughly $2-3$ times larger than that of the $\mathrm{MgO}$ phase $(7-10 \mathrm{~nm})$, as estimated from the peak width using the Debye-Scherrer equation. ${ }^{38}$

Figure 2 presents the weight loss rates of these HT compounds during heating in air, revealing the transformation of these $x$ CoMA-HTs into the corresponding oxides. In general, the thermal decomposition (weight loss) of the hydrotalcites consists 
TABLE 1: Textual Properties and NO $_{x}$ Adsorption Data of the Oxide Catalysts

\begin{tabular}{cccccc}
\hline sample & $\begin{array}{c}\text { SSA } \\
\left(\mathrm{m}^{2} / \mathrm{g}\right)\end{array}$ & $\begin{array}{c}\text { pore volume } \\
\left(\mathrm{cm}^{3} / \mathrm{g}\right)\end{array}$ & $\begin{array}{c}\text { pore size } \\
(\mathrm{nm})\end{array}$ & $\begin{array}{c}100{ }^{\circ} \mathrm{C} \\
(\mathrm{mg} / \mathrm{g})\end{array}$ & $\begin{array}{c}300{ }^{\circ} \mathrm{C} \\
(\mathrm{mg} / \mathrm{g})\end{array}$ \\
\hline 0.0CoMAO & 162.7 & 0.47 & 11.6 & 4.15 & 2.57 \\
0.5CoMAO & 157.8 & 0.44 & 11.1 & 6.65 & 4.14 \\
1.0CoMAO & 83.5 & 0.30 & 14.2 & 5.99 & 4.70 \\
1.5CoMAO & 55.3 & 0.24 & 17.2 & 5.22 & 4.96 \\
2.0CoMAO & 41.2 & 0.22 & 21.0 & 5.91 & 5.90 \\
2.5CoMAO & 21.6 & 0.13 & 24.8 & 5.61 & 5.90 \\
3.0CoMAO & 21.6 & 0.13 & 23.7 & 4.10 & 3.43
\end{tabular}

of two steps. The first step occurs at $100-250{ }^{\circ} \mathrm{C}$, and the maximum rate of weight loss is found at $210-220^{\circ} \mathrm{C}$ for all HT samples, mainly ascribed to the loss of interlayer and adsorbed water molecules. ${ }^{36}$ The second step of the weight loss at $250-500{ }^{\circ} \mathrm{C}$ consists of dehydroxylation of interlayer hydroxyl groups and decomposition of interlayer carbonate and nitrate (if any), resulting in the collapse of the layered structure. ${ }^{36,37}$ The corresponding differential thermal gravimetry (DTG) peak moves to a lower temperature from sample 0.0CoMA-HT to sample 3.0CoMA-HT, i.e., the HT structure is destabilized upon incorporation of cobalt into the hydroxide layers. This is understandable given that $\mathrm{Mg}(\mathrm{OH})_{2}$ is thermally more stable than $\mathrm{Co}(\mathrm{OH})_{2}{ }^{37,39,40}$ and is also reflected by the second peak temperatures of 0.0CoMA-HT $\left(\mathrm{Mg}_{3} \mathrm{Al} \mathrm{HT}, 444\right.$ $\left.{ }^{\circ} \mathrm{C}\right)$ and 3.0CoMA-HT $\left(\mathrm{Co}_{3} \mathrm{Al} \mathrm{HT}, 246{ }^{\circ} \mathrm{C}\right)$ in air (Figure 2). It is known that the decomposition of carbonate takes place at 250-600 ${ }^{\circ} \mathrm{C} .{ }^{36}$ However, the major weight loss in the second step for all samples occurs only around the peak temperature $\left( \pm 20-30^{\circ} \mathrm{C}\right)$. This could suggest that carbonate decomposition might be catalyzed by the incorporated cobalt in some way. In addition, for sample 3.0CoMA-HT, $\mathrm{Co}-\mathrm{OH}$ is partially dehydroxylated in the first step $^{39}$ as the two steps are partially overlapped (Figure 2). This, together with the oxidation of $\mathrm{Co}^{\mathrm{II}}$ to $\mathrm{Co}^{\mathrm{III}}$ in air during the collapse facilitates the formation of the spinel phase and thermally destabilizes $x$ CoMA-HT compounds. ${ }^{41}$

The BET surface area and pore volume are listed in Table 1 for the oxide catalysts derived from the corresponding HTlcs at $800{ }^{\circ} \mathrm{C}$ in air. Both the surface area and the pore volume of these oxide catalysts decrease with increasing cobalt content, as more spinel phase (big crystallites) is formed after calcination (Figure 1B). On the contrary, the average pore size between the crystallites increases. In particular, the pore size distribution (not shown here) indicates that all pores are over $2 \mathrm{~nm}$, and thus, gas molecule diffusion in these pores is not the ratedetermining step for adsorption and desorption.

TPR Analysis of $x$ CoMAO Catalysts. The reduction profiles of $x$ CoMAO samples are shown in Figure 3. It is very clear that the reduction behaviors of these catalysts are strongly related to the Co content in the oxide catalysts. For 0.0CoMAO, i.e., $\mathrm{Mg}_{3} \mathrm{Al}$ oxide, no reduction peaks were detected until $900{ }^{\circ} \mathrm{C}$, as expected. The positive baseline over $100^{\circ} \mathrm{C}$ might be caused by the impurity in the experimental setup. For all other Cocontaining oxide catalysts, reduction of cobalt proceeds largely in two stages, i.e., in the temperature ranges below and above $600{ }^{\circ} \mathrm{C}$. Obviously, the reduction over $600^{\circ} \mathrm{C}$ predominates in the TPR process, and the peak temperature decreases with increasing $\mathrm{Co}$ content, e.g., from 2.0CoMAO $\left(870{ }^{\circ} \mathrm{C}\right)$ to 2.5CoMAO $\left(820^{\circ} \mathrm{C}\right)$ to $3.0 \mathrm{CoMAO}\left(730^{\circ} \mathrm{C}\right)$. Even though we did not record data for samples 0.5-, 1.0-, and 1.5CoMAO below $900{ }^{\circ} \mathrm{C}$, similar trends could be expected. This stabilization effect of $\mathrm{Mg}$ on Co reduction is presumably attributed to the good dispersion of $\mathrm{Co}$ in the $\mathrm{MgAl}$ oxide matrix that obstructs

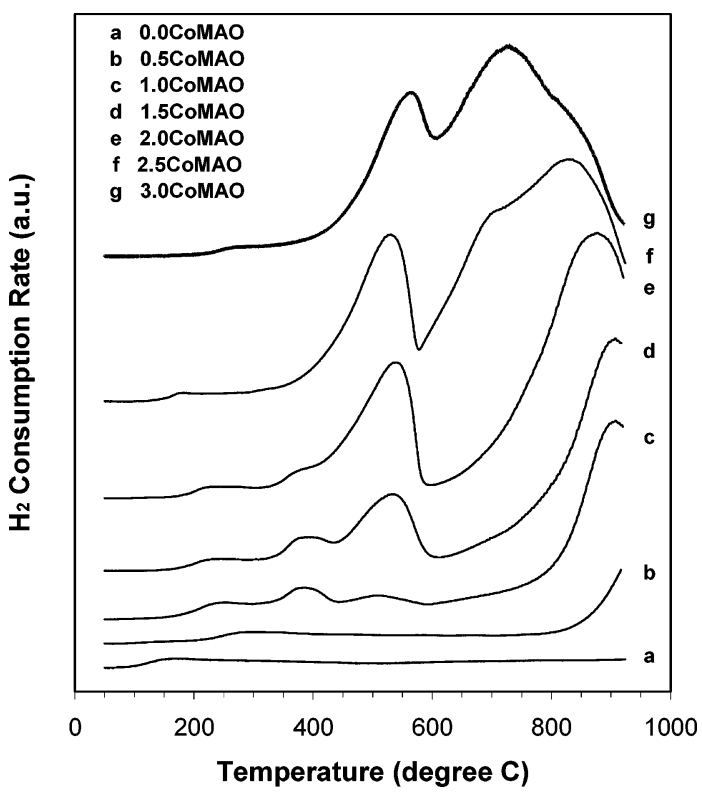

Figure 3. TPR profiles of catalysts $x \mathrm{CoMAO}$ in $\mathrm{H}_{2}$.

hydrogen from readily accessing the cobalt ions and delays the $\mathrm{Co}$ (II or III) reduction.

The low-temperature reduction below $600{ }^{\circ} \mathrm{C}$ involves three small steps. The Co reduction starts around $150-200{ }^{\circ} \mathrm{C}$ and continues to $300{ }^{\circ} \mathrm{C}$ at a relatively small magnitude. Between 300 and $450{ }^{\circ} \mathrm{C}$, there is a reduction slightly stronger than the former one (except for $0.5 \mathrm{CoMAO}$ ). The major reduction below $600{ }^{\circ} \mathrm{C}$ occurs at $450-600{ }^{\circ} \mathrm{C}$ (except for 0.5 - and $1.0 \mathrm{CoMAO}$ ). The peak temperature slightly increases from 510 to $570{ }^{\circ} \mathrm{C}$ from sample 1.0CoMAO to 2.5CoMAO, probably because of the difficulty in $\mathrm{H}_{2}$ approaching $\mathrm{Co}$ in larger spinel crystallites in samples containing higher levels of Co.

Because the final TPR compound for Co-containing oxide catalysts should be $\mathrm{Co}$ (metal)/MgAl oxide, it is reasonable to assign the high-temperature process to the reduction of bulky $\mathrm{Co}^{\mathrm{II}}$ cations dispersed in spinel and $\mathrm{MgO} .{ }^{42} \mathrm{On}$ this basis, we can assign the process at $510-570{ }^{\circ} \mathrm{C}$ to the reduction of bulky $\mathrm{Co}^{\mathrm{III}}$ cations in the spinel and $\mathrm{MgO}$ phases. As suggested, sample 3.0CoMAO has a formula of $\mathrm{Co}_{4 / 3} \mathrm{Co}^{\mathrm{III}}{ }_{5 / 3} \mathrm{AlO}_{16 / 3}$, so its reduction processes could be

$$
\mathrm{Co}_{4 / 3}^{\mathrm{II}} \mathrm{Co}_{5 / 3}^{\mathrm{III}} \mathrm{AlO}_{16 / 3} \rightarrow \mathrm{Co}_{3}{ }_{3} \mathrm{AlO}_{9 / 2} \rightarrow \mathrm{Co}(\text { metal }) / \mathrm{AlO}_{3 / 2}
$$

and the $\mathrm{H}_{2}$ consumption ratio in these two stages should be $5 / 3: 6$, i.e., 0.278. As calculated from the TPR profile, the real $\mathrm{H}_{2}$ consumption ratio at $400-590$ and $590-900{ }^{\circ} \mathrm{C}$ is 0.302 for catalyst 3.0CoMAO. Bearing in mind that some $\mathrm{Co}^{\mathrm{II}}$ is still not reduced when the sample is heated to $900{ }^{\circ} \mathrm{C}$ (curve $\mathrm{g}$ in Figure 3), the data agree well, supporting the assignments proposed above. In addition, two more minor steps at 150300 and $300-450{ }^{\circ} \mathrm{C}$ could be assigned to reduction of surface $\mathrm{Co}^{\mathrm{III}}$ and $\mathrm{Co}^{\mathrm{II}}$ on spinel and/or $\mathrm{MgO}$, respectively, as these cations are very easily accessed by $\mathrm{H}_{2}$ and readily reduced. ${ }^{36,43}$ The total consumption of $\mathrm{H}_{2}$ in these two minor steps is about $3.4 \%$ from the TPR profile of 3.0CoMAO, in acceptable agreement with the surface amount of Co (4.8\%) as estimated from the surface area in a previous report. ${ }^{44}$

NO $_{x}$ Adsorption on $\boldsymbol{x}$ CoMAO Catalysts. The adsorption profiles of $\mathrm{NO}_{x}$ on samples 0.0CoMAO, 1.5CoMAO, and 3.0CoMAO at 100 and $300{ }^{\circ} \mathrm{C}$ are presented in Figure 4. As expected, $\mathrm{NO}_{x}$ was adsorbed in the initial stage, as almost no $\mathrm{NO}_{x}$ was detected in the outlet stream. This adsorption lasted 

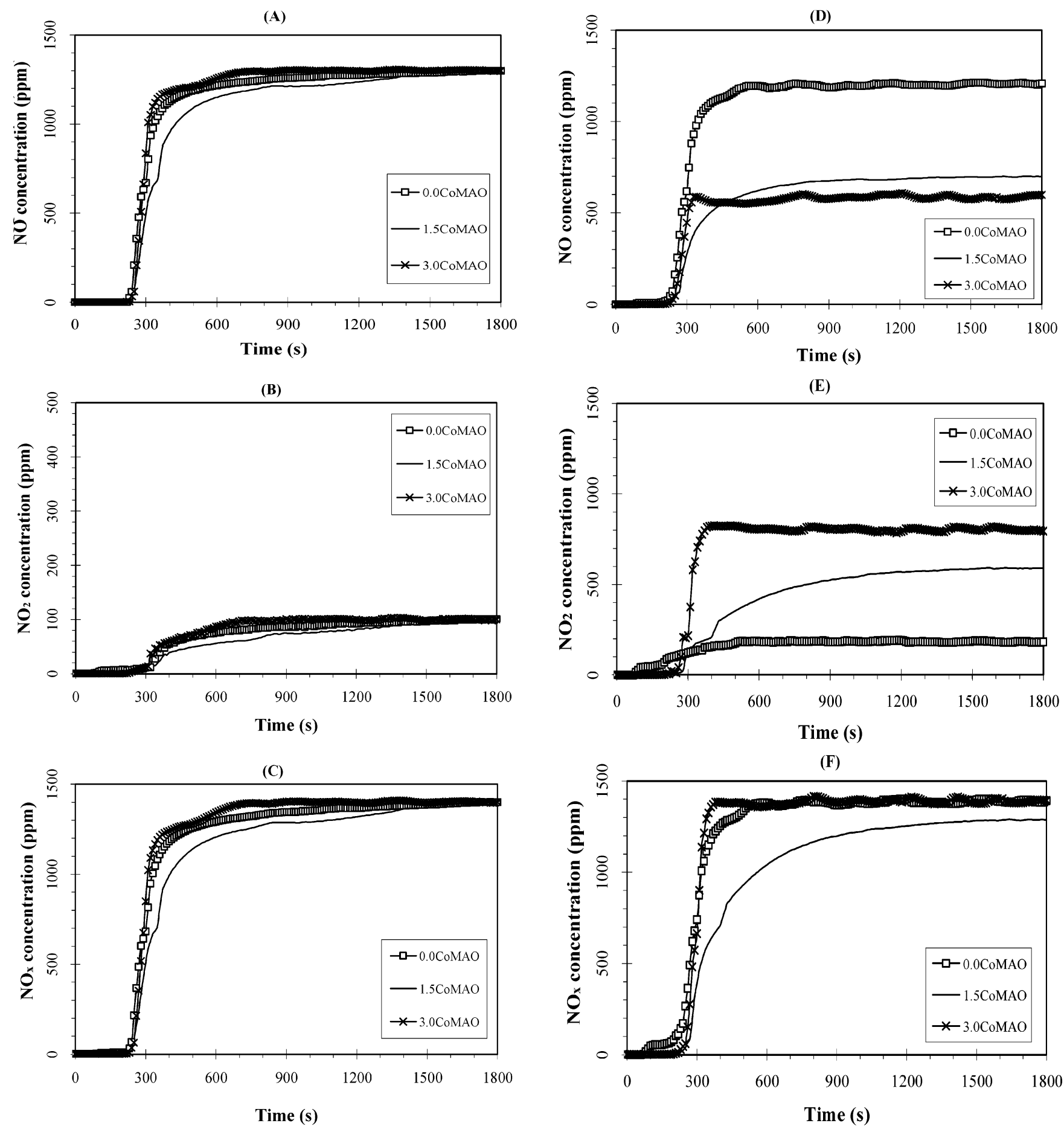

Figure 4. $\mathrm{NO}_{x}$ adsorption on catalysts $0.0-, 1.5-$, and 3.0CoMAO at $(\mathrm{A}-\mathrm{C}) 100$ and $(\mathrm{D}-\mathrm{F}) 300{ }^{\circ} \mathrm{C}$.

for $250 \mathrm{~s}$, and then the $\mathrm{NO}_{x}$ concentrations gradually recovered. At $100{ }^{\circ} \mathrm{C}$, the NO concentration recovered to $1200-1300 \mathrm{ppm}$ and the $\mathrm{NO}_{2}$ concentration to 90-100 ppm after $600 \mathrm{~s}$ for catalysts 0.0CoMAO and 3.0CoMAO (Figure 4A-C). Under the same conditions, the adsorption on catalyst $1.5 \mathrm{CoMAO}$ continues to slowly trap $\mathrm{NO}_{x}$ for $1500 \mathrm{~s}$.

At $300{ }^{\circ} \mathrm{C}$, the adsorption behavior of catalyst 0.0CoMAO for $\mathrm{NO}_{x}$ is similar to that at $100{ }^{\circ} \mathrm{C}$, with a slightly higher $\mathrm{NO}_{2}$ concentration (180 ppm) and a slightly lower NO concentration (1200 ppm) in the later adsorption period. However, other catalysts give much different gas compositions in the outlet stream. For example, catalyst 3.0CoMAO ( $\mathrm{Co}_{3} \mathrm{Al}$ oxide) increases $\mathrm{NO}_{2}$ concentration from $100 \mathrm{ppm}$ in the feed stream to $800 \mathrm{ppm}$ in the outlet stream while decreasing the NO concentration from 1300 to $600 \mathrm{ppm}$ after adsorption for about 350 s. This change in $\mathrm{NO}$ and $\mathrm{NO}_{2}$ concentrations indicates the conversion of $\mathrm{NO}$ to $\mathrm{NO}_{2}$ during passage through the $\mathrm{Co}_{3}-$ Al oxide catalyst. A similar phenomenon was observed for all of the other catalysts. Catalyst $1.5 \mathrm{CoMAO}$, as an example, gradually recovered the concentrations of $\mathrm{NO}, \mathrm{NO}_{2}$, and $\mathrm{NO}_{x}$ to 700,590 , and $1290 \mathrm{ppm}$, respectively after $1200 \mathrm{~s}$ of adsorption. The conversion from $\mathrm{NO}$ to $\mathrm{NO}_{2}$, i.e., the increase in $\mathrm{NO}_{2}$ amount, is plotted in Figure $5(\boldsymbol{\Delta})$. It can be noted that catalysts 0.0 CoMAO and 0.5CoMAO (lower Co loadings) increase the $\mathrm{NO}_{2}$ concentration by only $80-100 \mathrm{ppm}$ while the other catalysts increase the $\mathrm{NO}_{2}$ concentration by $400-800 \mathrm{ppm}$.

Another interesting observation is that the recovered $\mathrm{NO}_{x}$ concentration from catalyst $1.5 \mathrm{CoMAO}$ at $300{ }^{\circ} \mathrm{C}$ is always 


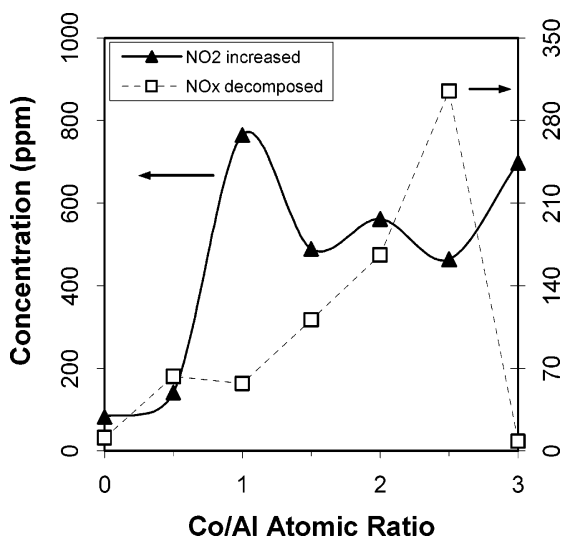

Figure 5. $\mathrm{NO}_{2}$ increase and $\mathrm{NO}_{x}$ decomposition at $300{ }^{\circ} \mathrm{C}$.

TABLE 2: NO $_{x}$ Desorption in Two Steps

\begin{tabular}{cccccc}
\hline & \multicolumn{2}{c}{ temperature range $\left({ }^{\circ} \mathrm{C}\right)$} & & \multicolumn{2}{c}{$\operatorname{DeNO}_{x}(\mathrm{~L}) / \mathrm{DeNO}_{x}(\mathrm{H})$} \\
\cline { 2 - 3 } \cline { 5 - 6 } sample & $\mathrm{L}$ & $\mathrm{H}$ & & $100{ }^{\circ} \mathrm{C}$ & $300{ }^{\circ} \mathrm{C}$ \\
\hline 0.0CoMAO & $100-435$ & $435-650$ & & 2.37 & 0.65 \\
0.5CoMAO & $100-290$ & $290-600$ & & 0.54 & 0.01 \\
1.0CoMAO & $100-280$ & $280-600$ & & 0.46 & 0.02 \\
1.5CoMAO & $100-280$ & $280-600$ & & 0.42 & 0.15 \\
2.0CoMAO & $100-280$ & $280-600$ & & 0.15 & 0.01 \\
2.5CoMAO & $100-330$ & $330-650$ & & 0.53 & 0.05 \\
3.0CoMAO & $100-295$ & $295-550$ & & 0.55 & 0.05
\end{tabular}

lower than that in the feed stream (1400 ppm). This suggests the partial decomposition of $\mathrm{NO}$ and/or $\mathrm{NO}_{2}$ to other kinds of nitrogen compounds (such as $\mathrm{N}_{2} \mathrm{O}, \mathrm{N}_{2}$ ) ${ }^{9}$ that were not detected by the chemiluminescence $\mathrm{NO}-\mathrm{NO}_{2}-\mathrm{NO}_{x}$ analyzer, as well as the continuous adsorption of $\mathrm{NO}_{x}$ on the catalysts. The latter seems not as likely because the adsorption is completed within $1500 \mathrm{~s}$ at $100{ }^{\circ} \mathrm{C}$ for all catalysts. The decomposed amount of $\mathrm{NO}_{x}$ is significantly affected by the Co loading in the tertiary catalysts, reaching a maximum of 300 ppm for catalyst 2.5CoMAO, as shown in Figure 5 ( $\square$ ). In comparison, binary catalysts (0.0CoMAO and 3.0CoMAO) decompose a limited amount of $\mathrm{NO}_{x}$ (about $10 \mathrm{ppm}$ ).

The adsorption (storage) data for $\mathrm{NO}_{x}$ on $x$ CoMAO samples at 100 and $300{ }^{\circ} \mathrm{C}$ were calculated from the desorption profile (refer to the next section) and are listed in Table 1. Note that, at both temperatures, the storage capacity of $\mathrm{NO}_{x}$ on threecomponent catalysts $x \mathrm{CoMAO}(0<x<3)$ is higher than that on two-component catalysts $x$ CoMAO $(x=0$ or 3$)$. As expected, the adsorption amount of $\mathrm{NO}_{x}$ at the higher temperature (300 $\left.{ }^{\circ} \mathrm{C}\right)$ is less than that at the lower temperature $\left(100^{\circ} \mathrm{C}\right)$, except for catalysts 2.0- and 2.5CoMAO.

NO $x$ Desorption from $\boldsymbol{x}$ CoMAO Catalysts. The desorption profiles of $\mathrm{NO}_{x}$ from typical catalysts $(0.0-, 1.5-$, and 3.0CoMAO) with storage of $\mathrm{NO}_{x}$ at 100 and $300{ }^{\circ} \mathrm{C}$ are shown in Figure 6. In general, $\mathrm{NO}_{x}$ desorption seems to follow a twostep process in the temperature range of $100-650{ }^{\circ} \mathrm{C}$. In the case of the non-Co-containing catalyst (0.0CoMAO), the desorption modes of $\mathrm{NO}_{x}$ adsorbed at 100 and $300{ }^{\circ} \mathrm{C}$ are quite similar, as can be seen from parts $\mathrm{N}$ and R of Figure $6(\square)$, only with different magnitudes in the two steps peaked at $310-$ 330 and $520-540{ }^{\circ} \mathrm{C}$, respectively. The ratio of the amounts of $\mathrm{NO}_{x}$ desorbed in these two steps $\left[\operatorname{DeNO}_{x}(\mathrm{~L}) / \mathrm{DeNO}_{x}(\mathrm{H})\right.$, Table 2] is 2.37 at $100{ }^{\circ} \mathrm{C}$ and 0.65 at $300{ }^{\circ} \mathrm{C}$. This could suggest that $\mathrm{NO}_{x}$ interacts with the catalyst in two different ways, where the weaker interaction characterizes various types of nitrites (corresponding to the desorption at $310-330{ }^{\circ} \mathrm{C}$ ) and the stronger one represents various types of nitrates (corresponding to the desorption at $520-540{ }^{\circ} \mathrm{C}$ ), as discussed in the following section. Obviously, the predominant desorbed species from catalyst 0.0CoMAO is NO. Similarly, the desorption of $\mathrm{NO}_{x}$ from catalyst 3.0CoMAO that was adsorbed at $100{ }^{\circ} \mathrm{C}$ underwent two similar steps, one at $255^{\circ} \mathrm{C}$ and the other at $355^{\circ} \mathrm{C}$, whereas these two steps occurred at much lower temperatures and over a much narrower temperature range (Figure 6 and Table 2), presumably because of the catalytic activity of cobalt for $\mathrm{NO}_{x}$ desorption. Interestingly, the $\mathrm{NO}_{x}$ absorbed at $300{ }^{\circ} \mathrm{C}$ on this catalyst desorbed only in the second step at about 360 ${ }^{\circ} \mathrm{C}\left(\left[\operatorname{DeNO}_{x}(\mathrm{~L}) / \operatorname{DeNO}_{x}(\mathrm{H})=0.05\right.\right.$, Table 2], suggesting that there are mainly strongly bound $\mathrm{NO}_{x}$ species, i.e., various nitrates, on the catalyst surface, as addressed in the following sections.

All other tertiary catalysts, represented by $1.5 \mathrm{CoMAO}$ as an example, undergo a similar desorption process. However, the two stages shift to lower temperatures by about $100{ }^{\circ} \mathrm{C}$ when compared to those of catalyst 0.0CoMAO (Figure 6 and Table 2). Table 2 also indicates that the desorbed amount of $\mathrm{NO}_{x}$ adsorbed at $100{ }^{\circ} \mathrm{C}$ in the first step is only about one-half or less than that desorbed in the second step, suggesting that Cocontaining catalysts either prefer the strong binding with $\mathrm{NO}_{x}$ or convert the weakly bound nitrites to strongly bound nitrates. This preference is more obvious for desorption of $\mathrm{NO}_{x}$ adsorbed at $300{ }^{\circ} \mathrm{C}$ as the desorbed $\mathrm{NO}_{x}$ in the first step can be ignored, meaning the nitrites formed on these catalysts are limited. In addition, the desorbed amount of $\mathrm{NO}_{2}$ is comparable to that of $\mathrm{NO}$ for these Co-containing catalysts, unlike the case where $\mathrm{NO}$ is predominant in non-Co-containing catalyst 0.0CoMAO, further suggesting that the major adsorbed $\mathrm{NO}_{x}$ species are nitrates.

Species Formed on $x$ CoMAO Catalysts. The storage/ decomposition mechanism of $\mathrm{NO}_{x}$ on catalysts $x \mathrm{CoMAO}$ can be revealed from the species formed during the adsorption/ desorption process. As described in the previous sections, NO and $\mathrm{NO}_{2}$ are all adsorbed in the initial adsorption stage, and then their concentrations in the outlet stream are recovered back to a certain level, suggesting that the adsorption/desorption process reaches a steady equilibrium. At $300{ }^{\circ} \mathrm{C}$, in particular, the $\mathrm{NO}_{2}$ concentration in the outlet stream $(180-870 \mathrm{ppm})$ is much higher than that in the feed (100 ppm), whereas the NO concentration $(500-1200 \mathrm{ppm})$ is much lower than that in the feed $(1300 \mathrm{ppm})$, indicating an apparent conversion of NO to $\mathrm{NO}_{2}$. Moreover, the $\mathrm{NO}_{x}$ total concentration in the outlet stream from tertiary catalysts $(0.5 \mathrm{CoMAO}-2.5 \mathrm{CoMAO})$ is much lower than the supplied $1400 \mathrm{ppm}$, revealing the decomposition of $\mathrm{NO}_{x}$, probably to $\mathrm{N}_{2}, \mathrm{O}_{2}$, and $\mathrm{N}_{2} \mathrm{O}$, on these catalysts. All of these gaseous species could be evolved through the desorption process, although $\mathrm{N}_{2}, \mathrm{O}_{2}$, and $\mathrm{N}_{2} \mathrm{O}$ were not directly determined in this research.

On the other hand, the adsorbed species are indicated by the in situ infrared spectra of the $\mathrm{NO}_{x}$-adsorbing catalysts. Briefly, they are various nitrites and nitrates, as well as some other nitrogen species, as summarized in Table 3. Their relative amounts, i.e., the IR peak intensities, are dependent on the adsorption time, the adsorption temperature, and the catalyst composition. As shown in Figure 7A for catalyst 0.0CoMAO $\left(\mathrm{Mg}_{3} \mathrm{Al}\right.$ oxide) as an example, the strong peak, initially located at $1246 \mathrm{~cm}^{-1}$ and then slightly shifted to $1263 \mathrm{~cm}^{-1}$, is attributed to bridging bidentate nitrite, due to the adsorption of NO. ${ }^{7,11,16,45}$ The other major band, initially located at $1709 \mathrm{~cm}^{-1}$ and later split into a broad band at $1641-1688 \mathrm{~cm}^{-1}$, belongs to bridging bidentate nitrate, attributed to $\mathrm{NO}_{2}$ adsorption. ${ }^{7,11,16}$ Some other species, such as monodentate nitrite, linear nitrite, and monodentate nitrate, which exhibit IR peaks at $1300-1500 \mathrm{~cm}^{-1}, 7,11,16$ 

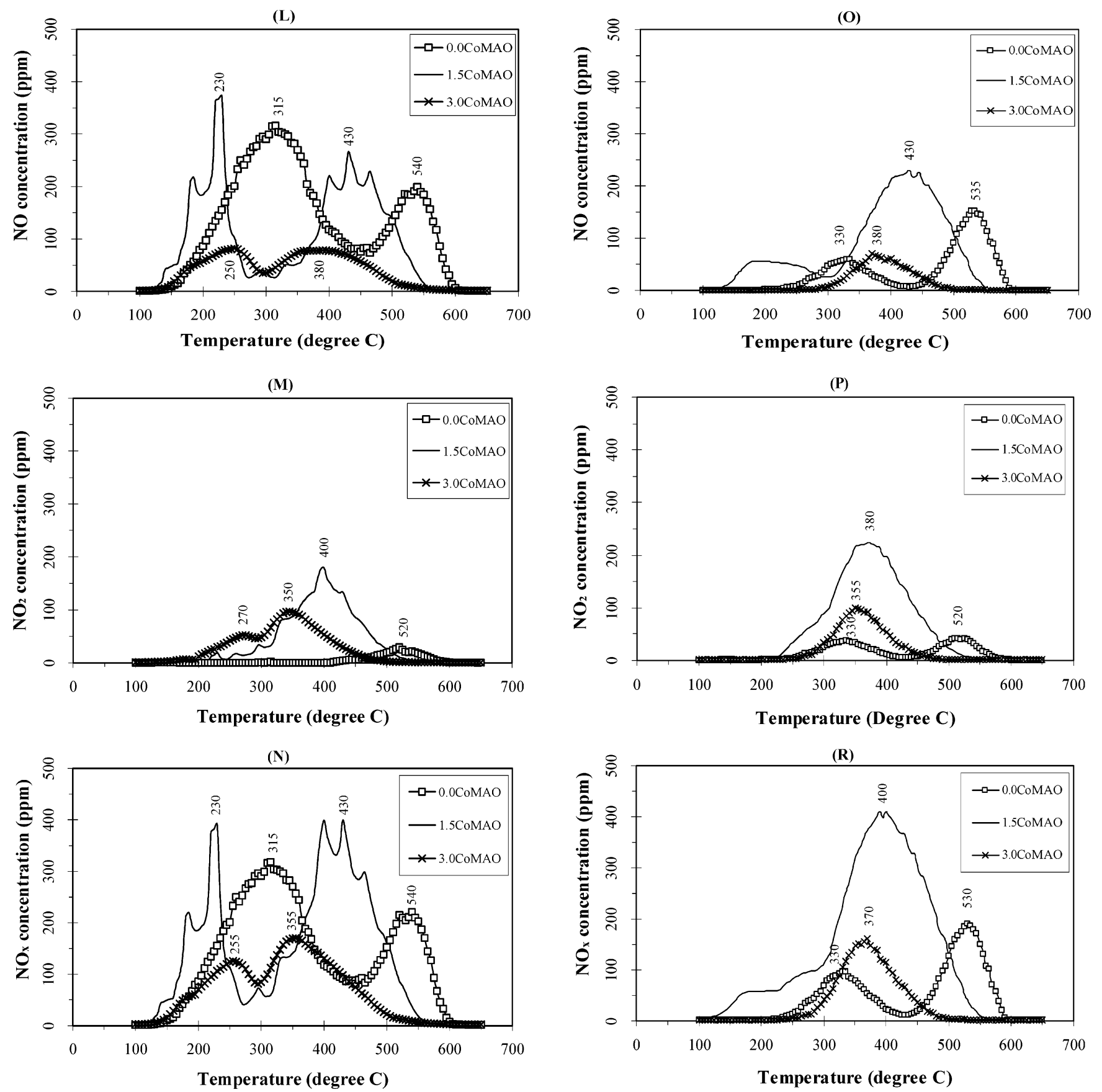

Figure 6. $\mathrm{NO}_{x}$ desorption profile on $0.0-, 1.5-$, and $3.0 \mathrm{CoMAO}$ at $(\mathrm{L}-\mathrm{N}) 100$ and $(\mathrm{O}-\mathrm{R}) 300{ }^{\circ} \mathrm{C}$.

as well as possibly $\mathrm{N}_{2} \mathrm{O}_{2}{ }^{2-}\left(1400 \mathrm{~cm}^{-1}\right),{ }^{16} \mathrm{~N}_{2} \mathrm{O}$ (adsorbed, 2009 $\left.\mathrm{cm}^{-1}\right),{ }^{9}$ and $\mathrm{NO}^{+}$(solid, 2332-2355 $\left.\mathrm{cm}^{-1}\right)^{46-48}$ are also present, (Table 3). The species adsorbed at $300^{\circ} \mathrm{C}$ (Figure 7B) are quite similar, only with a lower magnitude.

Similarly, for catalyst $1.5 \mathrm{CoMAO}\left(\mathrm{Co}_{1.5} \mathrm{Mg}_{1.5} \mathrm{Al}\right.$ oxides, Figure $8 \mathrm{~A}$ ), the peak at $1649-1636 \mathrm{~cm}^{-1}$ becomes stronger, indicating more bridging bidentate nitrates formed than for catalyst 0.0CoMAO. The initial peak at $1228-1240 \mathrm{~cm}^{-1}$ due to the adsorption of $\mathrm{NO}$ and assigned to bridging bidentate nitrite shifts to $1308 \mathrm{~cm}^{-1}$ as the strongest peak in the later adsorption stage that could be assigned to monodentate nitrate (also showing a peak at $\left.1034 \mathrm{~cm}^{-1}\right),{ }^{7,11,16}$ suggesting a redox conversion from bridging bidentate nitrite to monodentate nitrate in the presence of Co oxide. The other pronounced peak located at $1470 \mathrm{~cm}^{-1}$ belongs to the linear nitrite from adsorption of $\mathrm{NO}$ in the presence of Co oxide. ${ }^{16}$ For adsorption at $300{ }^{\circ} \mathrm{C}$ on catalyst 1.5CoMAO (Figure 8B), monodentate nitrate (1276, 1480 , and $1048 \mathrm{~cm}^{-1}$ ) is the major species, with some other possible minor species such as bridging bidentate nitrite (1276 $\left.\mathrm{cm}^{-1}\right),{ }^{7,11,16}$ adsorbed $\mathrm{N}_{2} \mathrm{O}_{4}\left(1726-1732 \mathrm{~cm}^{-1}\right),{ }^{46}$ chelating bidentate nitrate $\left(1553\right.$ and $\left.1276 \mathrm{~cm}^{-1}\right)$, and $\mathrm{NO}^{+}(2343$ $\left.\mathrm{cm}^{-1}\right) \cdot{ }^{46-48}$

The species adsorbed on catalyst 3.0CoMAO ( $\mathrm{Co}_{3} \mathrm{Al}$ oxide) are mainly various nitrates. For example, the adsorption of $\mathrm{NO}_{x}$ at $100{ }^{\circ} \mathrm{C}$ (Figure 9A) gives bridging bidentate [1628 (strongest), $1196 \mathrm{~cm}^{-1}$ ], monodentate $\left(1429,1345,1011 \mathrm{~cm}^{-1}\right)$ and chelating bidentate $\left(1511,1290 \mathrm{~cm}^{-1}\right)$ nitrates. ${ }^{7,11,16}$ The timedependent spectra (Figure 9A) clearly indicate that bridging bidentate nitrate $\left(1628 \mathrm{~cm}^{-1}\right)$ is gradually formed and become the major species in the final stage. However, this nitrate is almost gone for $300{ }^{\circ} \mathrm{C}$ adsorption, with some monodentate (1445 and $1354 \mathrm{~cm}^{-1}$ ) and chelating bidentate (1543-1583 


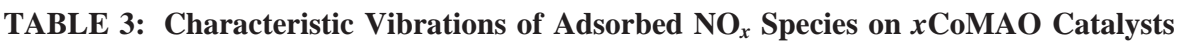

\begin{tabular}{|c|c|c|c|c|c|c|c|c|}
\hline \multirow[t]{2}{*}{ Structure } & \multirow[t]{2}{*}{$\mathrm{NO}_{\mathrm{x}}$ species } & \multicolumn{2}{|c|}{$\mathrm{Mg}_{3} \mathrm{Al}$-oxide } & \multicolumn{2}{|c|}{$\mathrm{Co}_{1.5} \mathrm{Mg}_{1.5} \mathrm{Al}$-oxide } & \multicolumn{2}{|c|}{$\mathrm{Co}_{3} \mathrm{Al}$-oxide } & \multirow[t]{2}{*}{ Vibration } \\
\hline & & $100^{\circ} \mathrm{C}$ & $300^{\circ} \mathrm{C}$ & $100^{\circ} \mathrm{C}$ & $300^{\circ} \mathrm{C}$ & $100^{\circ} \mathrm{C}$ & $300^{\circ} \mathrm{C}$ & \\
\hline$n-0-N=0$ & Linear nitrite & & & $1464-1471$ & $1477-1480$ & & & $v(\mathrm{~N}=\mathrm{O})$ \\
\hline & $\begin{array}{l}\text { Bridged bidentate } \\
\text { nitrite }\end{array}$ & $1246-1263$ & $1234-1261$ & $1228-1240$ & 1276 & $1196-1222$ & & $\begin{array}{l}v\left(\mathrm{NO}_{2}, \mathrm{~s}\right) \\
\mathrm{v}\left(\mathrm{NO}_{2}, \mathrm{as}\right)\end{array}$ \\
\hline & $\begin{array}{l}\text { Monodentate } \\
\text { nitrite }\end{array}$ & & & $\begin{array}{l}1464-1470 \\
1308\end{array}$ & & & & $\begin{array}{l}v(\mathrm{~N}=\mathrm{O}) \\
v(\mathrm{~N}-\mathrm{O})\end{array}$ \\
\hline & $\begin{array}{l}\text { Bridged bidentate } \\
\text { nitrate }\end{array}$ & $1636-1688$ & $1630-1678$ & $\begin{array}{l}1636-1649 \\
1308\end{array}$ & & $\begin{array}{l}1614-1632 \\
1345\end{array}$ & $\begin{array}{l}1637-1680 \\
1360-1377\end{array}$ & $\begin{array}{l}v(\mathrm{~N}=\mathrm{O}) \\
v\left(\mathrm{NO}_{2} \text {, as }\right)\end{array}$ \\
\hline & $\begin{array}{l}\text { Monodenate } \\
\text { nitrate }\end{array}$ & $1440-1450$ & $1450-1462$ & $\begin{array}{l}1464-1471 \\
1308 \\
1034\end{array}$ & $\begin{array}{l}1477-1483 \\
1276 \\
1048-1058\end{array}$ & $\begin{array}{l}1429 \\
1345 \\
1020\end{array}$ & $\begin{array}{l}1445-1454 \\
1360-1377\end{array}$ & $\begin{array}{l}v\left(\mathrm{NO}_{2}, \text { as }\right) \\
v\left(\mathrm{NO}_{2}, \mathrm{~s}\right) \\
v\left(\mathrm{NO}_{3}, \mathrm{~s}\right)\end{array}$ \\
\hline & $\begin{array}{l}\text { Chelating } \\
\text { bidentate nitrate }\end{array}$ & & & & $\begin{array}{l}1548-1553 \\
1276\end{array}$ & $\begin{array}{l}1511 \\
1290-1304\end{array}$ & $1540-1595$ & $\begin{array}{l}v(\mathrm{~N}=\mathrm{O}) \\
\mathrm{v}\left(\mathrm{NO}_{2}, \text { as }\right)\end{array}$ \\
\hline$\left(\mathrm{N}_{2} \mathrm{O}\right)_{\mathrm{ad}}$ & Adsorbed $\mathrm{N}_{2} \mathrm{O}$ & & 2009 & & & 2081 & & $v(N=N)$ \\
\hline$(\mathrm{NO})^{+}$ & Nitrosonium & $\begin{array}{l}2353-2355 \\
2559\end{array}$ & $\begin{array}{l}2332 \\
2532\end{array}$ & 2343 & & $\begin{array}{l}2315 \\
2573\end{array}$ & 2322 & $v(\mathrm{~N}=\mathrm{O})$ \\
\hline$\left(\mathrm{N}_{2} \mathrm{O}_{4}\right)_{\mathrm{ad}}$ & Adsorbed $\mathrm{N}_{2} \mathrm{O}_{4}$ & & & & $1726-1732$ & $1735-1753$ & $1732-1781$ & $v(\mathrm{~N}=\mathrm{O})$ \\
\hline$\left(\mathrm{N}_{2} \mathrm{O}_{2}\right)^{2-}$ & hyponitrite & $1400-1500$ & $1400-1500$ & & & 1345 & & $v(\mathrm{~N}-\mathrm{O})$ \\
\hline
\end{tabular}

$\mathrm{cm}^{-1}$ ) nitrates remaining. The other major species corresponding to the IR peaks at 1741 and $1781 \mathrm{~cm}^{-1}$ could be determined as adsorbed $\mathrm{N}_{2} \mathrm{O}_{4}$ (or $\mathrm{NO}^{+} \mathrm{NO}_{3}{ }^{-}$), ${ }^{46}$ together with peaks at 2322 $\left(\mathrm{NO}^{+}\right)$and $1300-1500 \mathrm{~cm}^{-1}\left(\mathrm{NO}_{3}{ }^{-}\right)$that can be also noted in the adsorption at $100{ }^{\circ} \mathrm{C}$.

Effect of Cobalt on Adsorption/Desorption. As presented previously, $\mathrm{Mg}_{3} \mathrm{Al}$ oxide catalyst can adsorb and store $\mathrm{NO}_{x}$ as various nitrites and nitrates that can be decomposed back to $\mathrm{NO}$ and $\mathrm{NO}_{2}$ during the desorption.

(a) adsorption

$$
\begin{aligned}
& 3 \mathrm{NO}_{2}+\mathrm{O}^{2-} \rightarrow 2 \mathrm{NO}_{3}^{-}+\mathrm{NO} \\
& \text { (disproportionation) (1) } \\
& 2 \mathrm{NO}_{2} \rightarrow \mathrm{N}_{2} \mathrm{O}_{4} \rightarrow \mathrm{NO}^{+} \mathrm{NO}_{3}^{-} \\
& \text {(disproportionation) } \\
& 4 \mathrm{NO}+2 \mathrm{O}^{2-} \rightarrow 2 \mathrm{NO}_{2}{ }^{-}+\mathrm{N}_{2} \mathrm{O}_{2}{ }^{2-} \\
& \text { (disproportionation) (3) } \\
& 4 \mathrm{NO}_{2}+\mathrm{O}_{2}+2 \mathrm{O}^{2-} \rightarrow 4 \mathrm{NO}_{3}^{-} \\
& 4 \mathrm{NO}+\mathrm{O}_{2}+2 \mathrm{O}^{2-} \rightarrow 4 \mathrm{NO}_{2}^{-}
\end{aligned}
$$

(b) desorption

$$
\begin{aligned}
& 4 \mathrm{NO}_{3}{ }^{-} \rightarrow 4 \mathrm{NO}_{2}+2 \mathrm{O}^{2-}+\mathrm{O}_{2} \\
& 4 \mathrm{NO}_{3}{ }^{-} \rightarrow 4 \mathrm{NO}+2 \mathrm{O}^{2-}+3 \mathrm{O}_{2} \\
& 4 \mathrm{NO}_{2}{ }^{-} \rightarrow 4 \mathrm{NO}+2 \mathrm{O}^{2-}+\mathrm{O}_{2}
\end{aligned}
$$

When the adsorption/desorption reaches a steady state, the apparent $\mathrm{NO}_{2}$ and $\mathrm{NO}$ concentrations do not change. The oxygen produced in reactions $6-8$ could coordinate the oxidation of $\mathrm{NO}$ into $\mathrm{NO}_{2}{ }^{-}$and $\mathrm{NO}_{2}$ into $\mathrm{NO}_{3}{ }^{-}$, as shown in reactions 4 and 5.
As cobalt is incorporated into the catalyst, similarly to $\mathrm{Cu}$ and $\mathrm{Pt}$, some adsorption reactions are catalytically accelerated, leading to more $\mathrm{NO}_{x}$ adsorbed (Table 1). In particular, the following redox reactions probably take place much more quickly than reactions 4 and 5

$$
\begin{gathered}
\mathrm{NO}+\mathrm{Co}^{3+}-\mathrm{O}^{2-} \rightarrow \mathrm{Co}^{2+}-\mathrm{NO}_{2}{ }^{-} \\
\mathrm{NO}_{2}+\mathrm{Co}^{3+}-\mathrm{O}^{2-} \rightarrow \mathrm{Co}^{2+}-\mathrm{NO}_{3}^{-}
\end{gathered}
$$

where surface $\mathrm{Co}^{3+}$ (or $\mathrm{Co}^{2+}$ ) acts as the oxidant that can facilitate the adsorption of $\mathrm{NO}$ and $\mathrm{NO}_{2}$. As we found that cobalt-containing oxide starts reduction in $\mathrm{H}_{2}$ stream at 150$200{ }^{\circ} \mathrm{C}$, so reactions 9 and 10 take place in $\mathrm{NO}_{x}$ adsorption at $300{ }^{\circ} \mathrm{C}$. In contrast, the presence of Co can also facilitate the decomposition of nitrites and nitrates. The catalytic activities of cobalt oxide for adsorption and desorption seem to be similar in magnitude, as we note that the $\mathrm{NO}_{\mathrm{x}}$ adsorption amount of catalyst 3.0 CoMAO $\left(\mathrm{Co}_{3} \mathrm{Al}\right.$ oxide $)$ is quite similar to that of catalyst $0.0 \mathrm{CoMAO}\left(\mathrm{Mg}_{3} \mathrm{Al}\right.$ oxide) at $100-300{ }^{\circ} \mathrm{C}$ (Table 1). However, the tertiary catalysts can take up much more $\mathrm{NO}_{x}$ (Table 1). It is suggested that higher $\mathrm{NO}_{x}$ adsorption is due to a migration process of $\mathrm{NO}_{3}{ }^{-}$and $\mathrm{NO}_{2}{ }^{-}$from $\mathrm{Co}$ to adjacent $\mathrm{Mg} / \mathrm{Al}$ to form relatively stable $\mathrm{Mg} / \mathrm{Al}$ nitrates and nitrites. ${ }^{12,49}$ Therefore, a careful tradeoff between $\mathrm{Co}$ and $\mathrm{Mg} / \mathrm{Al}$ in the oxide structure and composition might lead to a powerful $\mathrm{NO}_{x}$ adsorbent catalyst, such as $2.5 \mathrm{CoMAO}$, which shows a rather high $\mathrm{NO}_{x}$ adsorption at $300{ }^{\circ} \mathrm{C}$ that is comparable to that of perovskites at the same temperature. ${ }^{10}$

The presence of cobalt in the catalysts also causes a significant conversion of $\mathrm{NO}$ to $\mathrm{NO}_{2}$ and a noticeable decomposition of $\mathrm{NO}_{x}$ at $300{ }^{\circ} \mathrm{C}$, as shown in Figure 5. It is known that $\mathrm{NO}_{x}$ (mainly NO) is catalytically decomposed on transition metal oxides, probably to $\mathrm{N}_{2}$ and $\mathrm{O}_{2} \cdot{ }^{9,12,17,30}$ The as-produced oxygen can enhance the apparent conversion of $\mathrm{NO}$ to $\mathrm{NO}_{2}$ via (i) 


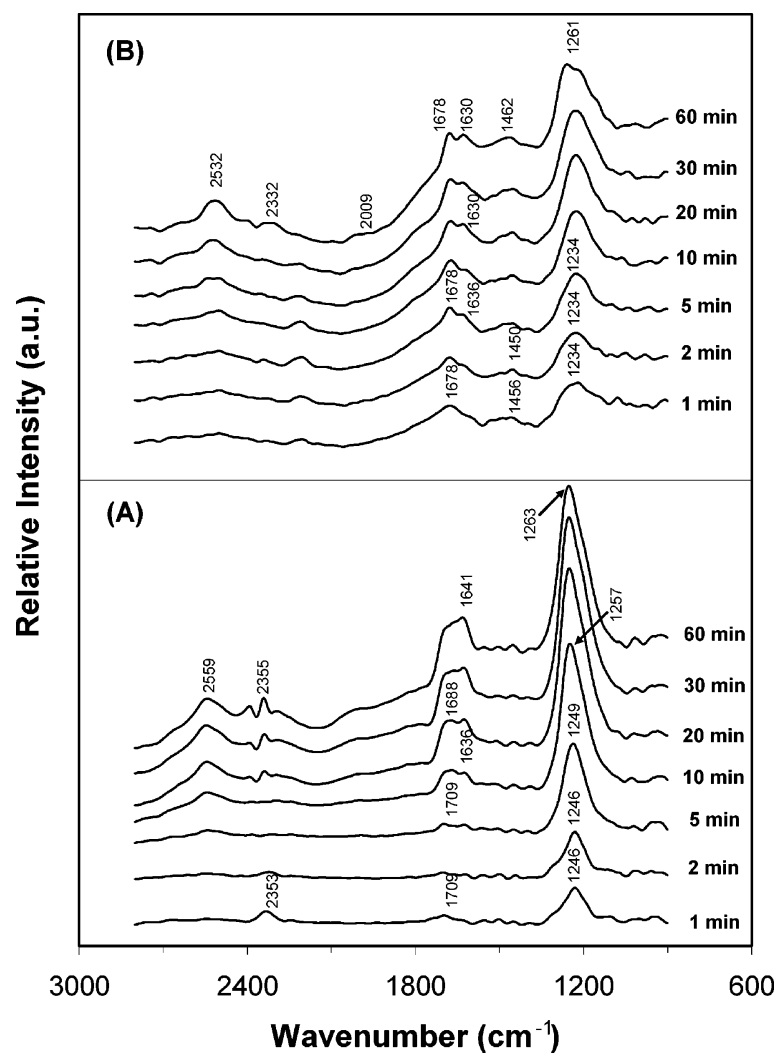

Figure 7. In situ IR spectra of $\mathrm{NO}_{x}$ adsorption on catalyst $0.0 \mathrm{CoMAO}$ at (A) 100 and (B) $300{ }^{\circ} \mathrm{C}$.

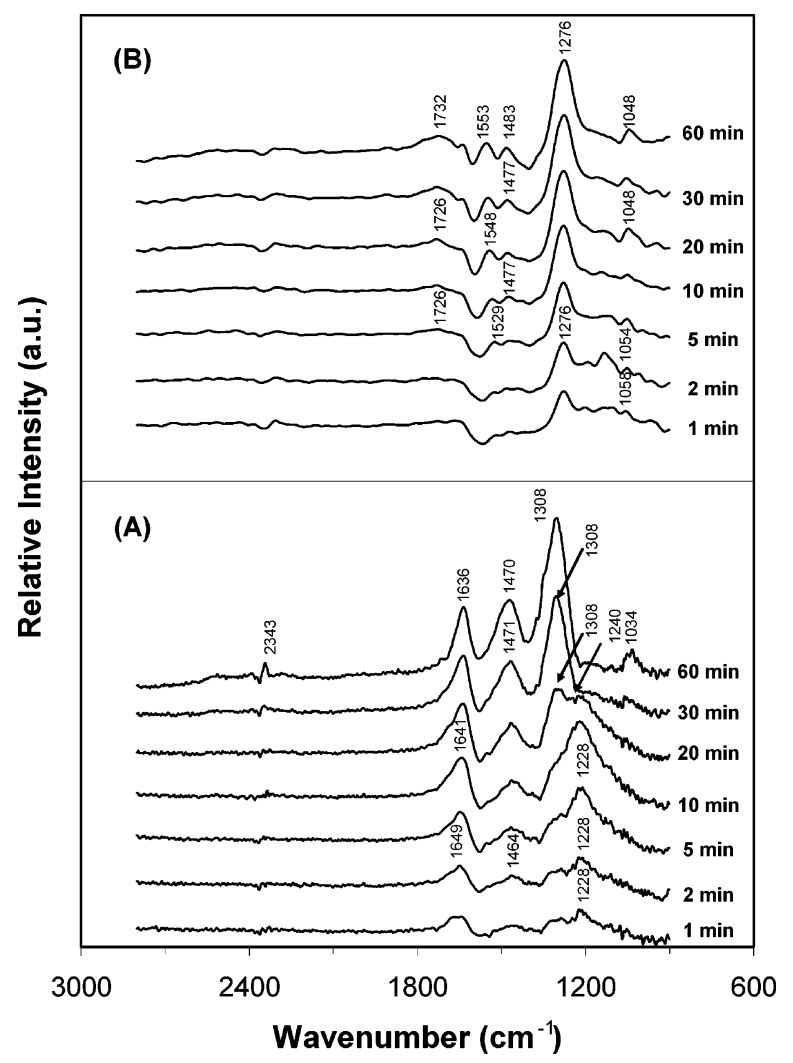

Figure 8. In situ IR spectra of $\mathrm{NO}_{x}$ adsorption on catalyst 1.5CoMAO at (A) 100 and (B) $300{ }^{\circ} \mathrm{C}$.

reaction 5 to form more nitrites and/or (ii) reaction 11 to convert more nitrites to nitrates

$$
2 \mathrm{NO}_{2}^{-}+\mathrm{O}_{2} \rightarrow 2 \mathrm{NO}_{3}^{-}
$$

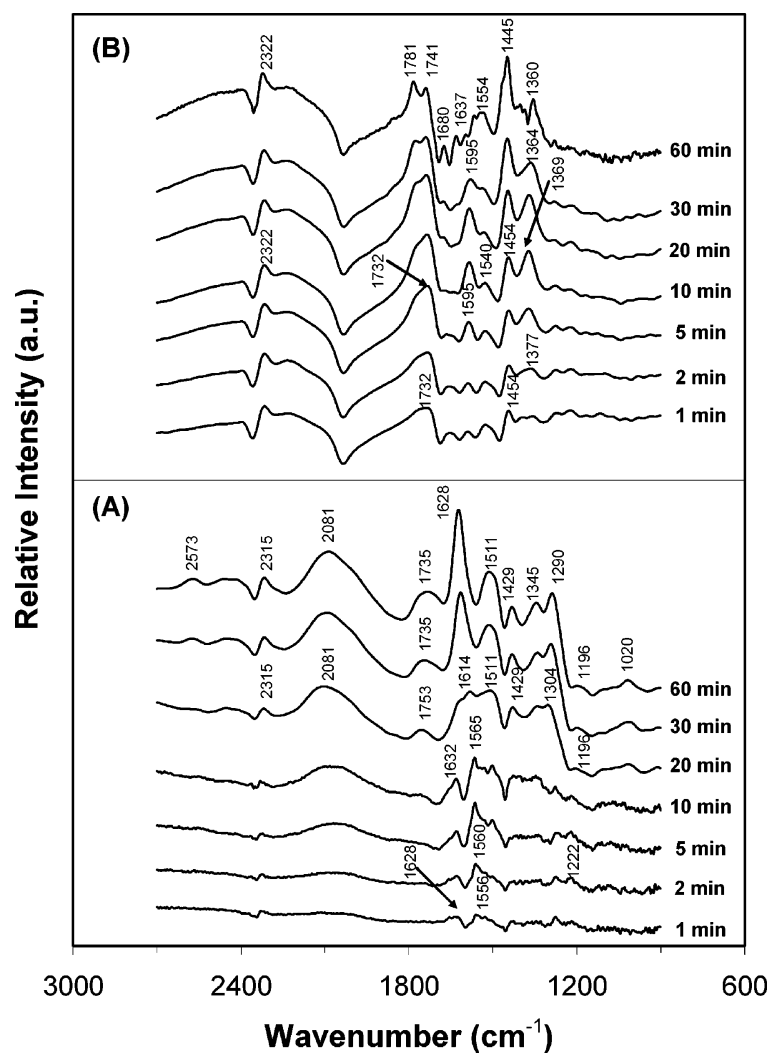

Figure 9. In situ IR spectra of $\mathrm{NO}_{x}$ adsorption on catalyst 3.0CoMAO at (A) 100 and (B) $300{ }^{\circ} \mathrm{C}$.

Then, the nitrates decompose to give $\mathrm{NO}_{2}$. The overall stoichiometric reaction is

$$
4 \mathrm{NO} \rightarrow 2 \mathrm{NO}_{2}+\mathrm{N}_{2}
$$

This could account for the $\mathrm{NO}_{2}$ concentration increase by $50-$ $150 \mathrm{ppm}$. Most of the increase in the $\mathrm{NO}_{2}$ concentration from $\mathrm{NO}$ is suggested to be due to the direct oxidation of $\mathrm{NO}_{2}{ }^{-}$to $\mathrm{NO}_{3}{ }^{-}$by the supplied $\mathrm{O}_{2}$ on the Co oxide surface, as shown in reaction 11. Other possible reactions that could account for the conversion are

$$
\begin{gathered}
\mathrm{Co}^{2+}-\left(\mathrm{NO}_{2}^{-}\right)_{2} \rightarrow \mathrm{Co}^{0}+2 \mathrm{NO}_{2} \\
\mathrm{Co}^{2+}-\mathrm{NO}_{2}^{-}+\mathrm{O}^{2-} \rightarrow \mathrm{Co}^{0}+\mathrm{NO}_{3}^{-}
\end{gathered}
$$

These reactions might also be responsible for the comparable $\mathrm{NO}_{2}$ amounts desorbed from 100 to $650{ }^{\circ} \mathrm{C}$ in comparison to $\mathrm{NO}$ for Co-containing catalysts adsorbing at $300{ }^{\circ} \mathrm{C}$ (Figure $6 \mathrm{O}-\mathrm{R})$. In addition, these reactions could also take place during $100{ }^{\circ} \mathrm{C}$ adsorption and subsequent desoprtion, although the degree could be very minimal and unnoticeable for some reactions.

\section{Conclusions}

$\mathrm{Co}-\mathrm{Mg} / \mathrm{Al}$ hydrotalcite-like compounds were prepared via a coprecipitation process and identified by their XRD patterns. Their transformation to mixed oxides upon calcination was also confirmed by XRD patterns and TG analysis. The more cobalt incorporated, the more spinel phase formed, which influences the $\mathrm{NO}_{x}$ adsorption/decomposition. The surface areas of the derived oxides ( $x$ CoMAO) decreased from 162.7 to $21.6 \mathrm{~m}^{2} / \mathrm{g}$ with increasing Co content from $x=0.0$ to $x=3.0$. 
The investigation of the reduction behaviors of $x$ CoMAO catalysts indicates that the surface cobalt cations $\left(\mathrm{Co}^{\mathrm{II}}\right.$ and $\left.\mathrm{Co}^{\mathrm{III}}\right)$ were first reduced by $\mathrm{H}_{2}$ at $150-450{ }^{\circ} \mathrm{C}$, and then the reductions of the bulky $\mathrm{Co}^{\mathrm{III}}$ to $\mathrm{Co}^{\mathrm{II}}\left(450-600{ }^{\circ} \mathrm{C}\right)$ and the bulky $\mathrm{Co}^{\mathrm{II}}$ to $\mathrm{Co}^{0}\left(>600{ }^{\circ} \mathrm{C}\right)$ took place. The storage capacities of $\mathrm{NO}_{x}$ for tertiary catalysts were higher than those for binary catalysts, with $0.5 \mathrm{CoMAO}$ adsorbing the most $\mathrm{NO}_{x}(6.6 \mathrm{mg} / \mathrm{g})$ at $100{ }^{\circ} \mathrm{C}$ and 2.0CoMAO and 2.5CoMAO adsorbing the most $\mathrm{NO}_{x}(5.9$ $\mathrm{mg} / \mathrm{g}$ ) at $300{ }^{\circ} \mathrm{C}$. During the $\mathrm{NO}_{x}$ adsorption at $300{ }^{\circ} \mathrm{C}$ on the tertiary catalysts, the catalytic conversion from $\mathrm{NO}$ to $\mathrm{NO}_{2}$ and the catalytic decomposition of $\mathrm{NO}_{x}$ were observed. The in situ IR spectra suggest that the major adsorbed species are various nitrites and nitrates, with some minor species such as $\mathrm{N}_{2} \mathrm{O}_{2}{ }^{2-}$, $\mathrm{N}_{2} \mathrm{O}_{4}$ (or $\mathrm{NO}^{+} \mathrm{NO}_{3}{ }^{-}$), and $\mathrm{N}_{2} \mathrm{O}$. However, the relative amounts of these species depend on the catalyst composition and the adsorption temperature. On the basis of the various adsorbed species, an adsorption/desorption mechanism has been discussed. Cobalt oxide has been proposed to facilitate the oxidation of $\mathrm{NO}$ to nitrites and nitrates that move to adjacent $\mathrm{Mg} / \mathrm{Al}$ oxide to be more stably stored in the tertiary catalysts, revealing that carefully balancing the adsorption and storage by controlling the $\mathrm{Co} / \mathrm{Mg}$ ratio in the current system could lead to an optimum absorbent catalyst for NSR.

Acknowledgment. This work was supported by the National Basic Research Program of China (2004CB719500), the key project of Knowledge Innovation of Chinese Academy of Sciences (KZCX3-SW-430), and a project of Natural Science Foundation of China (20322201).

\section{References and Notes}

(1) Taylor, K. Catal. Rev.-Sci. Eng. 1993, 35, 457.

(2) Zwinkels, M. M.; Jara, S. G.; Menon, P. G. Catal. Rev.-Sci. Eng. 1993, 35, 319

(3) Heck, R. M.; Ferrauto, R. J. Catalytic Air Pollution Control; Van Nostrand Reinhold: New York, 1995.

(4) Shelef, M. Chem. Rev. 1995, 95, 209.

(5) Matsumoto, S. Catal. Today 1996, 29, 43.

(6) Shinjoh, H.; Takahashi, N.; Yokota, K.; Sugiura, M. Appl. Catal. $B$ 1998, 15, 189.

(7) Prinetto, F.; Ghiotti, G.; Nova, I.; Lietti, L.; Tronconi, E.; Forzatti, P. J. Phys. Chem. B 2001, 105, 12732.

(8) Olsson, L.; Persson, H.; Fridell, E.; Skoglundh, M.; Andersson, B. J. Phys. Chem. B 2001, 105, 6895.

(9) Garin, F. Appl. Catal. A 2001, 222, 183.

(10) Hodjati, S.; Vaezzadeh, K.; Petit, C.; Pitchon, V.; Kiennemann, A. Appl. Catal. B 2000, 26, 5 .

(11) Su, Y.; Amiridis, M. D. Catal. Today 2004, 96, 31.

(12) Centi, G.; Arena, G. E.; Perathoner, S. J. Catal. 2003, 216, 443.

(13) Huang, H. Y.; Long, R. Q.; Yang, R. T. Energy Fuels 2001, 15, 205.

(14) Karen, S. K.; Rachel, L. M.; Michael, P. H. Catal. Today 2004, 96,79

(15) Uy, D.; Wiegand, K. A.; O’Neill, A. E.; Dearth, M. A.; Weber,

W. H. J. Phys. Chem. B 2002, 106, 387.

(16) Sedlmair, Ch.; Seshan, K.; Jentys, A.; Lercher, J. A. J. Catal. 2003, 214,308 .
(17) Centi, G.; Fornasari, G.; Gobbi, C.; Livi, M.; Trifirò F.; Vaccari, A. Catal. Today 2002, 73, 287.

(18) Fornasari, G.; Trifirò, F.; Vaccari, A.; Prinetto, F.; Ghiotti, G.; Centi, G. Catal. Today 2002, 75, 421 .

(19) Yamazaki, K.; Takahashi, N.; Shinjoh, H.; Sugiura, M. Appl. Catal. B 2004, 53, 1 .

(20) Hodjati, S.; Petit, C.; Pitchon, V.; Kiennemann, A. Appl. Catal. B 2001, 30, 247.

(21) Li, X. G.; Chen, J. F.; Lin, P. Y.; Meng, M.; Fu, Y. L.; Tu, J.; Li, Q. X. Catal. Commun. 2004, 5, 25.

(22) Brilhac, J.-F.; Sultana, A.; Gilot, P.; Martens, J. A. Environ. Sci. Technol. 2002, 36, 1136.

(23) Sultana, A.; Habermacher, D. D.; Kirschhock, C. E. A.; Martens, J. A. Appl. Catal. B 2004, 48, 65.

(24) Szanyi, J.; Kwak, J. H.; Moline, R. A.; Peden, C. H. F. Phys. Chem. Chem. Phys. 2003, 5, 4045

(25) Fornasari, G.; Glöckler, R.; Livi, M.; Vaccari, A. Appl. Clay Sci. 2005, 29, 258.

(26) Palomares, A. E.; López-Nieto, J. M.; Lázaro, F. J.; López A.; Corma A.; Appl. Catal. B 1999, 20, 257.

(27) Cavani, F.; Triro, F.; Vaccari, A. Catal. Today 1991, 11, 173.

(28) Braterman, P. S.; Xu, Z. P.; Yarberry, F. In Handbook of Layered Materials; Auerbach S. M., Carrado, K. A., Dutta, P. K., Eds.; Marcel Dekker: New York, 2004; p 373.

(29) Montanari, B.; Vaccari, A.; Gazzano, M.; Kapner, P.; Papp, H.; Dziembaj, R.; Makowski, W.; £ojewski, T.; Dziembaj, R. Appl. Catal. B 1996, 16, 205

(30) Kang, S. F.; Jiang, Z.; Hao, Z. P. Acta Phys. Chim. Sin. 2005, 21, 278 .

(31) Yu, J. J.; Jiang, Z.; Kang, S. F.; Hao, Z. P.; Hu, C. Chin. Chem. Phys. 2005, 18, 251.

(32) Corma, A.; Palomares, A. E.; Marquez, F. J. Catal. 1997, 170, 132.

(33) Shannon, I. J.; Rey, F.; Sankar, G.; Thomas, J. M.; Maschmayer, T.; Waller, A. W.; Palomares, A. E.; Corma, A.; Dent, A. J.; Greaves, G. N. J. Chem. Soc. 1996, 92, 4331.

(34) Bookin, A. S.; Drits, V. A. Clays Clay Miner. 1993, 41, 551.

(35) Xu, Z. P.; Lu, G. Q. Chem. Mater. 2005, 17, 1055.

(36) Chmielarz, L.; Kustrowski, P.; Rafalska-Lasocha, A.; Dziembaj, R. Thermochim. Acta 2003, 395, 225.

(37) Xu, Z. P.; Zeng, H. C. J. Phys. Chem. B 2000, 104, 10206

(38) Cullity, B. D. Elements of X-ray Diffraction, 2nd ed.; AddisonWesley: Reading, MA, 1978; p 278.

(39) Xu, Z. P.; Zeng, H. C.: J. Mater. Chem. 1998, 8, 2499

(40) Halikia, I.; Economacou, A. Int. J. Chem. Kinet. 1993, 25, 609.

(41) Xu, Z. P.; Zeng, H. C. Chem. Mater. 2000, 12, 3459.

(42) Arnoldy, P.; Moulijn, J. A. J. Catal. 1985, 93, 38.

(43) Shanmugam, Y.; Lin, F.-Y.; Chang, T.-H.; Yeh, C.-T. J. Phys. Chem. B 2003, 107, 1044 .

(44) In a sphere model of spinel crystallites, the ratio of the surface cobalt to the total cobalt is estimated as follows: $\mathrm{Co}_{\text {surface }}=V_{\text {surface }} / V=$ $\left(4 \pi r^{2} t\right) /\left(4 \pi r^{3} / 3\right)=3 t / r=4.8 \%$, for $r=25 \mathrm{~nm}$ (particle radius) and $t=$ $0.40 \mathrm{~nm}$ (two $\mathrm{Co}-\mathrm{O}$ bond lengths, the thickness of surface $\mathrm{Co}$ ).

(45) Nova, I.; Castoldi, L.; Lietti, L.; Tronconi, E.; Forzatti, P.; Prinetto, F.; Ghiotti, G. J. Catal. 2004, 222, 377.

(46) Perdana, I.; Creaser, D.; Ohrman, O.; Hedlund, J. J. Catal. 2005, $234,219$.

(47) Cotton, F. A., Wilkinson, G.; Murillo, C. A.; Bochmann, M. Advanced Inorganic Chemistry; John Wiley \& Sons: New York, 1999; p 326

(48) Nakamoto, K. Infrared and Raman Spectra of Inorganic and Coordinate Compounds; John Wiley \& Sons: New York, 1997; Part A, pp 160 and 166.

(49) Paterson, A. J.; Rosenberg, D. J.; Anderson, J. A. Stud. Surf. Sci. Catal. 2001, 138, 429. 